\title{
SELECTED STRENGTH ASPECTS OF ADHESIVE LAP JOINTS AND BUTT WELDED JOINTS OF VARIOUS STRUCTURAL MATERIALS
}

\author{
Anna Rudawska', Paweł Niedziałkowski', Izabela Miturska', Jakub Szabelski', \\ Dominik Grzesiczak ${ }^{2}$
}

1 Lublin University of Technology, ul. Nadbystrzycka 36, 20-618 Lublin, Poland, e-mail: a.rudawska@pollub.pl, pawelniedzialkowski@o2.pl, i.miturska@pollub.pl, j.szabelski@pollub.pl

5 Czestochowa University of Technology, ul. Armii Krajowej 19C, 42-201 Częstochowa, Poland, e-mail: grzesiczak@ipp.pcz.pl

Received: 2017.11 .17

Accepted: 2018.02.01

Published: 2018.03.01

\begin{abstract}
The present paper evaluates the effect of joining method on the strength of joint assemblies of selected structural materials: DX51+Z275 galvanised steel, OH18N9 stainless steel and DC01 low carbon steel. The objects of the study are: the lap adhesive joint and the butt welded joint with continuous and spot weld. Welded joints were produced latter by means of one of the two welding methods, MIG or MAG. The choice of the welding method depended on the type substrate material. Welding was conducted at the following constant technological parameters: strength of current, electrode deposition rate, filler metal diameter, type and flow rate of shielding gas. The adhesive joint was bonded with Epidian 53/Z1/100:10 epoxy adhesive. The substrates were pre-treated in a threestage surface preparation process involving: mechanical treatment with P60 and P320 abrasive tools and degreasing with Loctite 7063 degreasing agent. The tensile strength tests, conducted under the study, provided strength characteristics of the tested joint assemblies, indicating differences in the values of strength that depended on the applied joining method or, in the case of welded joints, the structure of the seam.
\end{abstract}

Keywords: adhesive joints, welded joints, tensile strength, MIG/MAG, failure load

\section{INTRODUCTION}

The technology of metal joining dates back to the 19th century $[4,16]$. Since its beginning the method has been driven by the developments in the structural materials technology and the incessant need for materials of highly customary properties, which must be joined to form often intricate structures. At present, welding is used in a wide range of applications and industries. The process of welding consists in forming a permanent joint of separate elements. Bonding between the materials occurs at the atomic/molecular level, which ensures high strength and durability. It is therefore impossible to disjoin two welded elements without breaking the bond. Joints formed in welding, are thus referred to as connecting or permanent joints.
Permanent joints are present in various branches of engineering and enable joining heterogeneous materials, to form structures that could not otherwise be produced, e.g.by means of casting. The family of permanent joining techniques includes: welding, pressure welding, soldering, and adhesive joining. The technology of making adhesive joints to the overlap allows to obtain a higher static tensile strength compared to butt joints. In the case of welding, butt-welding rather than overlapping is used more often in constructions. This is due, among other things, to the possibility of subsequent treatment of the weld in order to achieve an aesthetic effect, as well as to be aware of the strength. For this reason, such designs have been used in the tests. 
The present paper aims to evaluate the effect of two joining technologies on the strength of three structural materials: DX51+Z275 galvanised steel, OH18N9 stainless steel and DC01 low carbon steel. The objects of the study were two types of joints: single lap adhesive joints, butt welded with continuous weld and spot weld, which were formed on the analysed substrate material. The results of our study provide data determining the suitability of the two joining techniques under the criterion of joint strength.

\section{ADHESIVE JOINING TECHNOLOGY}

Adhesive joining is an invaluable addition to classic methods for joining structural materials. Today, it is widely applicable in various branches of industry, such as: building, automotive, aviation, machine building or packaging industry. Joining metals by means of adhesive bonding is increasingly common and its popularity is attributed to a considerable strength of the adhesive joint, lack of stresses in the joint and cost-effectiveness of the method, due to a small amount of adhesive required to form a single-lap joint. Moreover, adhesive bonding is used to dampen vibrations, it enables joining substrates without the machine tool engagement, or the need for employing expensive tools and materials (even though in certain applications the cost of technological instrumentation could prove significantly high); lack of electrochemical phenomena usually accompanying other methods of joining metals, and the joining of dissimilar structural materials, frequently of substantial disproportions in geometric dimensions $[5,6,8]$.

In present days, adhesive joining is frequently applied in bonding polymer composite and metal substrates. Structural adhesive bonding is an indispensable method of joining thin-walled elements of sandwich construction, whose advantages are lightness and rigidity, which are essential properties in aircraft constructions [8]. Adhesive bonding technology comprises several consecutive technological operations: surface treatment, preparation and application of adhesive, joining substrates, cure, conditioning, finishing and joint quality control $[4,5,8]$. Individual operations may consist of a number of stages of specific technological parameters; they might also require various items of equipment and instrumentation. Detailed conditions of adhesive bonding operation are selected based on, inter alia, the type of substrate, the geometry of elements and structures, joint assembly conditions, production type, etc [11].

\section{WELDING TECHNOLOGY}

Welded joints, representing the permanent joint family, are formed by joining elements of parent material with the aid of a filler material using thermal energy until the filler material and the edge of substrates is melted. The joint formed in welding is composed of several characteristic elements: weld seam, heat affected zone in parent material, parent material, weld toe, weld root, weld face and fused zone. The developments in welding technology have led to their great diversification, and therefore several types of welding may be distinguished; and this is arc welding that constitutes one of the largest groups. The application of this technology is relative to the type of substrate material, type of electrode, and the use of shielding gas. The experimental part of this paper describes formation of joints in a gas-shielded metal-arc welding process, which is suitable in shop or difficult assembly conditions. Gas-shielded metal-arc welding may be further divided into MIG/MAG welding, where the solid wire consumable electrode is used, and the arc and pool are shielded by gas [7]. MIG (Metal Inert Gas) is a process employing a chemically neutral gas, such as argon or helium. MAG (Metal Active Gas), on the other hand, makes use of chemically active shielding gas, such as $\mathrm{CO}_{2}$. These methods are applied whenever high quality metal joints are required, in such applications as carbon steel, alloys, aluminium and copper [14]. In both MIG and MAG methods welding parameters play a crucial role. The parameters determining the quality of joint are as follows [7]:

- type and strength of current[A],

- arc voltage [V],

- welding speed [m/min],

- type and flow rate of shielding gas [1/min],

- filler metal diameter [mm],

- electrode stick-out [mm],

- electrode deposition rate [m/min],

- electrode or joint angle $\left[{ }^{\circ}\right]$.

The weld seam produced in the process may differ in terms of shape, which together with the technique employed exerts impact on the strength and load-carrying capacity of the joint. The experimental tests performed in the study were aimed 
at evaluating butt welded joints performed with a continuous and spot weld. The butt welded joint finds application in joining substrates of equal thickness. Butt weld is recognised for high static and dynamic strength exhibited by joints and easy access in terms of joint quality control for all available methods. In static strength tests butt welded joints frequently manifest higher strength than the parent material itself $[4,9,15]$.

\section{TEST METHODOLOGY}

The objects of the study were single lap adhesive joints and butt welded joints with a continuous and spot weld. In the experimental part of this study the joints were produced with the substrates presented below. 10 specimens of each joint variant were produced and subjected to testing.

\section{Characteristics of substrates}

The substrate materials subjected to strength testing, i.e. DX51+Z275 galvanised steel, OH18N9 stainless steel and DC01 low carbon steel, were cut to size: length $100 \mathrm{~mm}$, width 40 $\mathrm{mm}$, thickness $1 \mathrm{~mm}$. The chemical composition of each metal sheet is shown in Table 1. Each of the materials joined and analysed in the study is widely used in different industries. The materials in question exhibit dissimilar strength properties, corrosion resistance and machinability.

\section{Adhesive joints characteristics.}

The geometry of the single lap adhesive joint is shown in Figure 1.

The overlap length was obtained from the relationship described in detail in [5], which gives the "limit" overlap length in a joint of substrates of equal thickness. Theoretical discussion in [3] indicates that by increasing the length of the overlap beyond "limit" should not, according to Volkersen's theory, impart higher strength on the joint. Therefore, the overlap length of specimens was specified to be $15 \mathrm{~mm}$.

Prior to adhesive bonding, the following surface treatment operations were performed:

- mechanical treatment with a P60 abrasive tool,

- mechanical treatment with a P320 abrasive tool,

- degreasing with Loctite 7063 degreasing agent

The adhesive joints under testing were produced with Epidian 53/Z1/100:10 epoxy adhesive. The adhesive was prepared immediately before application on the surface of one of the adherends. The joints were made at the temperature of $24^{\circ} \mathrm{C}$ and relative humidity equal to $24 \%$. Subsequently, the joints were cured under the compressive load of $20 \mathrm{~N}$ and subjected to 4 days of seasoning.

\section{Characteristics of butt welded joints}

The other joint type analysed in the study was the butt welded joint with a continuous and spot

Table1. Chemical composition of substrate materials [10]

\begin{tabular}{|c|c|c|c|c|c|c|c|c|c|}
\hline \multirow{2}{*}{ Material } & \multicolumn{9}{|c|}{ Chemical composition [\%] } \\
\hline & $\mathrm{C}$ & $\mathrm{Mn}$ & $P$ & $\mathrm{~S}$ & Si & $\mathrm{Ti}$ & $\mathrm{Cr}$ & $\mathrm{Ni}$ & $\mathrm{N}$ \\
\hline DX51+Z275 galvanised steel & 0.12 & 0.6 & 0.1 & 0.045 & 0.6 & 0.3 & - & - & - \\
\hline OH18N9 stainless steel & 0.08 & 2.0 & 0.045 & 0.03 & 0.75 & - & 19.0 & 10.0 & 0.1 \\
\hline DC01 low carbon steel & 0.12 & 0.6 & 0.045 & 0.045 & - & - & - & - & - \\
\hline
\end{tabular}
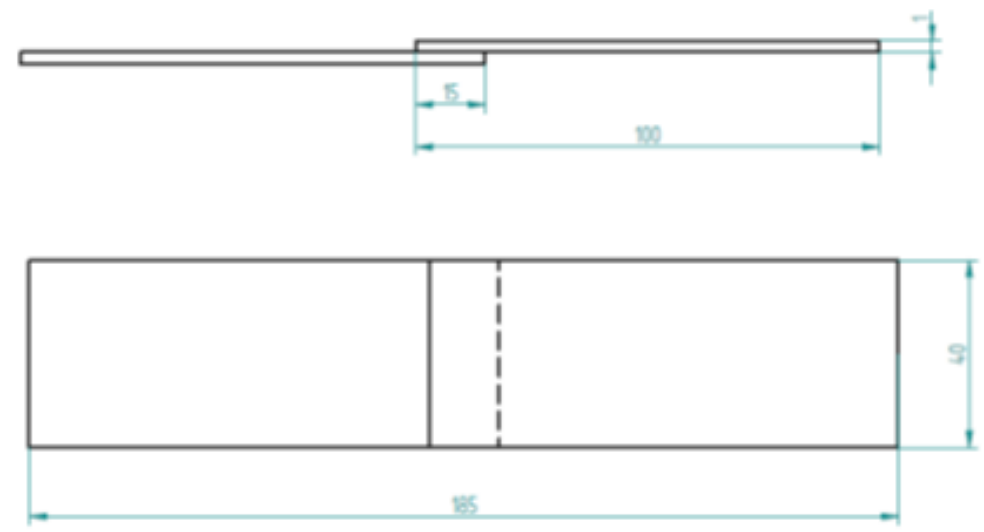

Fig. 1.Dimensions of single lap adhesive joint specimens used in tests 
weld, produced with the same substrates as in the adhesive joints. The schematic of the analysed butt welded joint is shown in Fig. 2.

Butt welded joint samples were produced with a $1 \mathrm{~mm}$ gap between the substrates. Two welding technologies were applied to prepare the samples, MIG and MAG welding, at constant technological parameters of welding, such as: strength of current, electrode deposition rate, filler metal diameter, type and flow rate of shielding gas. The parameters, shown in Table 2, were specified for each substrate material, as was the type of welding technology.

The joints were welded at a temperature of $26^{\circ} \mathrm{C}$ and relative humidity of $26 \%$. The surface of substrates was subjected to surface treatment with P60 aloxite grit abrasive tool prior to welding.

\section{TEST RESULTS}

\section{Test results of adhesive joints}

Test were conducted on single lap adhesive joints on three types of substrates: DX51+Z275 galvanised steel, OH18N9 stainless steel, DC01 low carbon steel. The strength of joints was evaluated by means of destructive testing, which was conducted according to DIN EN 1465 [2]. Test results are shown in Table 3. For adhesive joint samples was determined tensile lap-shear strength [1].

Strength test results are shown in Figure 3. In adhesive joints the results slightly differed, as the highest strength was recorded for DC01 low carbon steel and the lowest for joint assemblies of galvanised steel. On the basis of the statistical analysis carried out, no significant differences were observed between the obtained results.

\section{Test results of welded joints}

Test were conducted on butt welded joints with continuous and spot weld on three types of substrates: DX51+Z275 galvanised steel, OH18N9 stainless steel, DC01 low carbon steel. The strength of joints was evaluated by means of destructive testing, which was conducted according to DIN EN ISO 527-1 [3]. Test results are shown in Table 4. For welded

a)

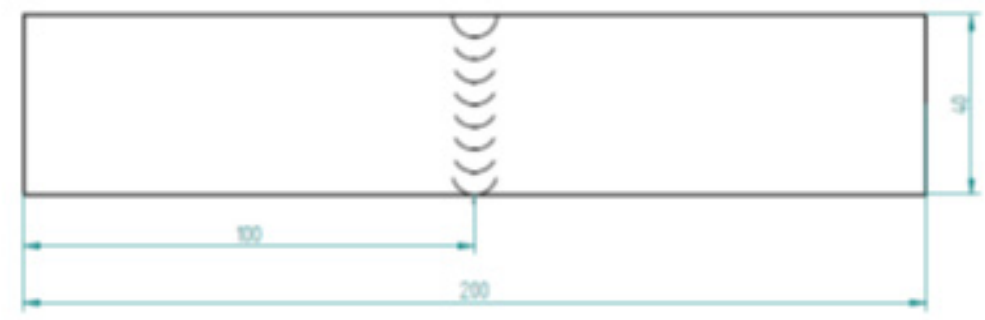

b)

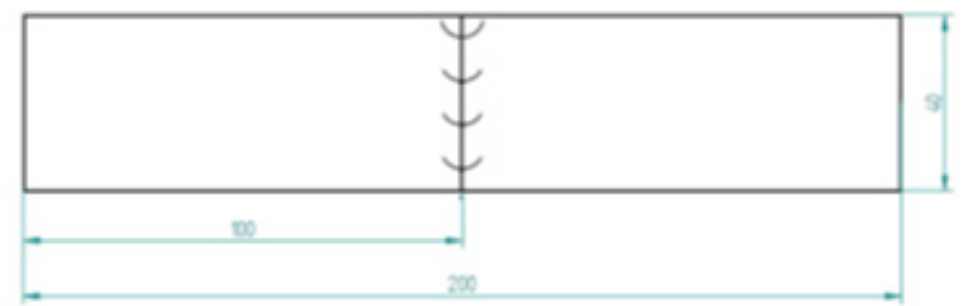

Fig. 2. Schematic of butt welded joint: a) continuous weld, b) spot weld

Table 2. Technical and technological conditions for welding

\begin{tabular}{|l|c|c|c|c|c|c|}
\hline Substrate material & $\begin{array}{c}\text { Welding } \\
\text { method }\end{array}$ & Shielding gas & $\begin{array}{c}\text { Shielding gas } \\
\text { flow rate [l/min] }\end{array}$ & $\begin{array}{c}\text { Filler material } \\
\text { diameter [mm] }\end{array}$ & $\begin{array}{c}\text { Electrode } \\
\text { deposition rate [m/ } \\
\text { min] }\end{array}$ & $\begin{array}{c}\text { Strength of } \\
\text { current [A] }\end{array}$ \\
\hline $\begin{array}{l}\text { DX51+Z275 } \\
\text { galvanised steel }\end{array}$ & MIG & $\begin{array}{c}\text { Inert gas }(82 \% \\
\left.\mathrm{Ar}, 18 \% \mathrm{CO}_{2}\right)\end{array}$ & 12 & 0.8 & 6 & 80 \\
\hline $\begin{array}{l}\text { OH18N9 stainless } \\
\text { steel }\end{array}$ & MIG & $\begin{array}{c}\text { Inert gas }(82 \% \\
\left.\mathrm{Ar}, 18 \% \mathrm{CO}_{2}\right)\end{array}$ & 12 & 1.0 & 6 & 80 \\
\hline $\begin{array}{l}\text { DC01 low carbon } \\
\text { steel }\end{array}$ & MAG & $\mathrm{CO}_{2}$ & 10 & 0.8 & 8 & 100 \\
\hline
\end{tabular}


Table 3. Strength test results for single lap adhesive joint

\begin{tabular}{|c|l|c|c|c|c|}
\hline Joint type & Substrate material & $\begin{array}{c}\text { Average failure } \\
\text { load [N] }\end{array}$ & $\begin{array}{c}\text { Standard deviation } \\
{[\mathrm{N}]}\end{array}$ & $\begin{array}{c}\text { Average shear } \\
\text { strength [MPa] }\end{array}$ & $\begin{array}{c}\text { Standard } \\
\text { deviation [MPa] }\end{array}$ \\
\hline \multirow{2}{*}{$\begin{array}{c}\text { Single lap adhesive } \\
\text { joint }\end{array}$} & $\begin{array}{l}\text { OH18N9 stainless } \\
\text { steel }\end{array}$ & 2704.76 & 617.93 & 4.42 & 0.98 \\
\cline { 2 - 6 } & $\begin{array}{l}\text { DX51+Z275 } \\
\text { galvanised steel }\end{array}$ & 2056.75 & 715.14 & 3.26 & 1.04 \\
\cline { 2 - 6 } & $\begin{array}{l}\text { DC01 low carbon } \\
\text { steel }\end{array}$ & 2878.65 & 545.44 & 4.71 & 0.92 \\
\hline
\end{tabular}

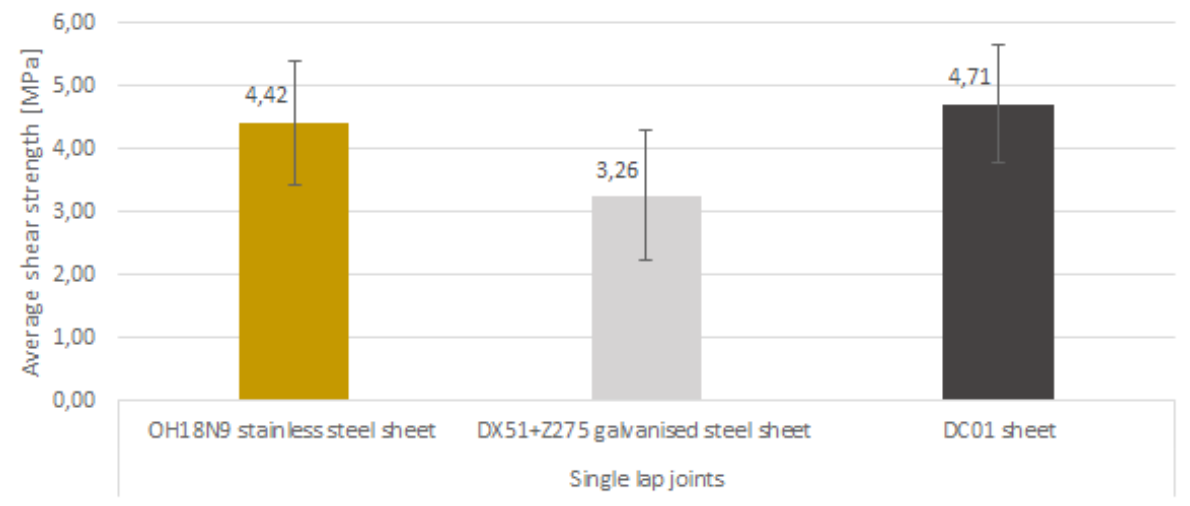

Fig. 3. Strength of adhesive joints

Table 4. Strength test results for welded joint

\begin{tabular}{|c|l|c|c|c|c|}
\hline Joint type & Substrate material & $\begin{array}{c}\text { Average failure } \\
\text { load [N] }\end{array}$ & $\begin{array}{c}\text { Standard deviation } \\
{[\mathrm{N}]}\end{array}$ & $\begin{array}{c}\text { Average tensile } \\
\text { strength [MPa] }\end{array}$ & $\begin{array}{c}\text { Standard } \\
\text { deviation [MPa] }\end{array}$ \\
\hline \multirow{2}{*}{$\begin{array}{c}\text { Wentinuous weld } \\
\text { Weint }\end{array}$} & $\begin{array}{l}\text { OH18N9 stainless } \\
\text { steel }\end{array}$ & 20313.04 & 1803.72 & 149.54 & 5.79 \\
\cline { 2 - 6 } & $\begin{array}{l}\text { DX51+Z275 } \\
\text { galvanised steel }\end{array}$ & 14135.23 & 659.20 & 111.73 & 7.89 \\
\cline { 2 - 6 } & $\begin{array}{l}\text { DC01 low carbon } \\
\text { steel }\end{array}$ & 11806.83 & 752.72 & 77.34 & 5.49 \\
\hline & $\begin{array}{l}\text { OH18N9 stainless } \\
\text { steel }\end{array}$ & 16734.18 & 1876.89 & 213.87 & 27.68 \\
\cline { 2 - 6 } & $\begin{array}{l}\text { DX51+Z275 } \\
\text { galvanised steel }\end{array}$ & 12324.14 & 265.25 & 115.37 & 8.62 \\
\cline { 2 - 6 } & $\begin{array}{l}\text { DC01 low carbon } \\
\text { steel }\end{array}$ & 9696.31 & 1229.48 & 84.84 & 16.56 \\
\hline
\end{tabular}

joints samples was determined tensile strength, and expressed as maximum tensile stress sustained by the test specimen referred to the original cross-section of the joint [1].

The presented test results indicate that the welded joint exhibits higher strength in all analysed configurations. However, favourable results are obtained for welded joint with spot weld produced with the MIG method for stainless and galvanised steel. The results show that the load required for the welded joint to fail is several times higher than the failure load in the adhesive joint, hence welded joints exhibit higher strength. Strength test results are shown in Figure 4.
Analysis of strength of joints shows that joints welded by means of the MIG method exhibited higher strength than the MAGwelded ones. Furthermore, the type of weld seam that provided superior strength was the spot weld. With regards to substrate material, the highest strength was obtained in the case of OH18N9 stainless steel, and the lowest in joints formed on DC01 low carbon specimen. The statistical analysis of the significant differences test showed that the obtained results fit into different homogeneous groups, which means that a significant difference in the assumed significance level $\alpha=0.05$ is noticeable between the results. 


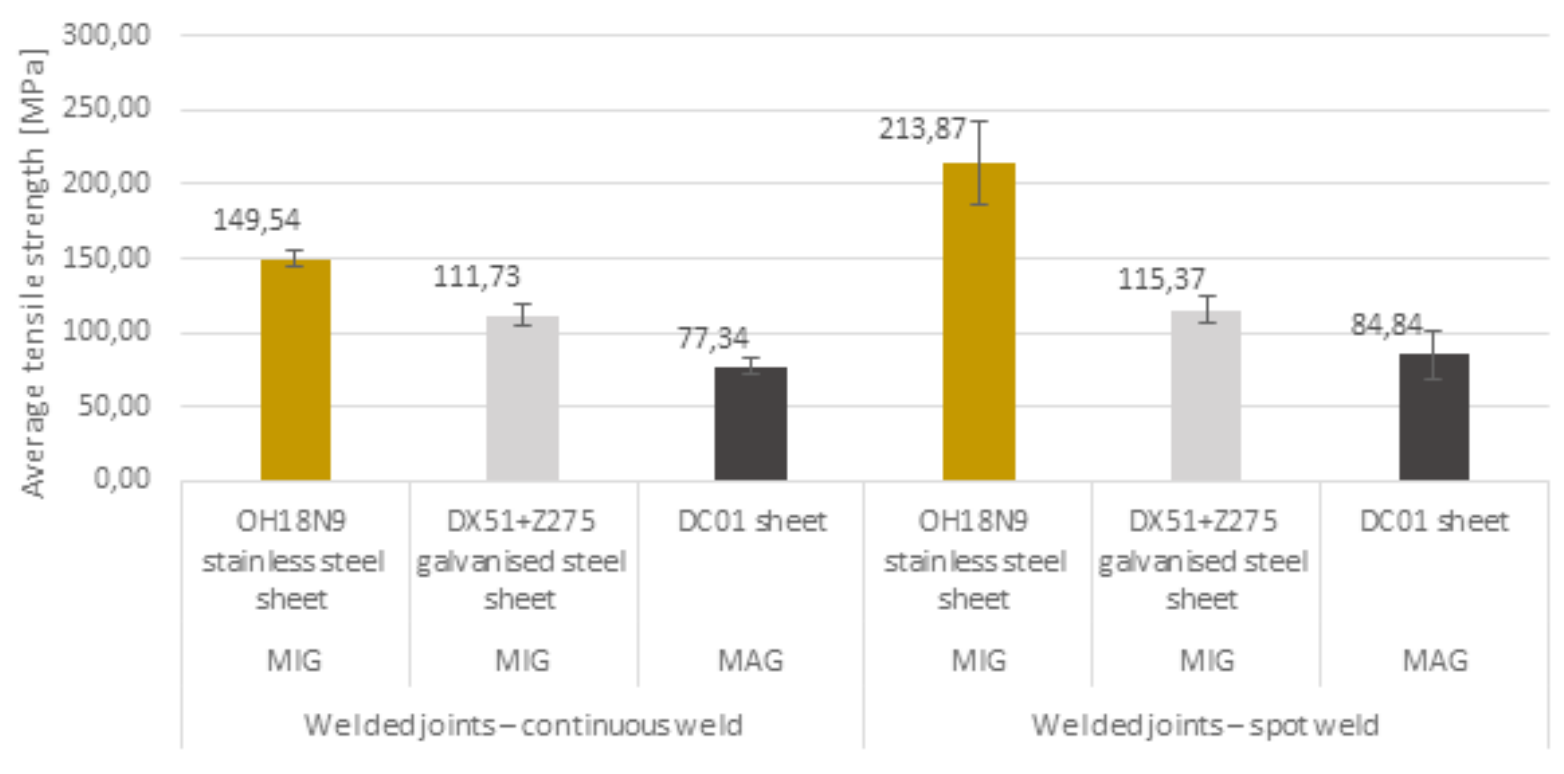

Fig. 4. Strength of butt joints

\section{SUMMARY AND CONCLUSIONS}

This paper assessed the effect of joining method on the strength of joint assemblies of selected structural materials: DX51+Z275 galvanised steel, OH18N9 stainless steel and DC01 low carbon steel. The objects of the study were two types of joints: the lap adhesive joint and the butt welded joint with continuous or spot weld. The former joint was produced with Epidian 53/Z1/100:10 epoxy adhesive, and the latter by means of one of the two welding methods, MIG or MAG, the choice of which depended on the substrate material.

Strength test for adhesive joints revealed that:

- in shear tests the structural steel adhesive joint proved the strongest,

- the highest value of maximum failure load in the adhesive joint was measured in the structural steel,

Strength test for welded joints revealed that:

- the highest value of maximum failure load in welded joints in the stainless steel with continuous and spot weld,

- in the welded joints the best performance in strength tests was observed for the spot weld joints,

- in comparison the MIG performs better in strength tests than the MAG method,
In both joining methods this was galvanised steel that exhibited the worst performance in strength tests.

In conclusion, our work highlights that owing to the existence of numerous factors that may distort the values obtained in tests, joint assembly conditions must be closely observed. The results from the study indicate that the spot weld ensures better strength properties of a joint than the continuous weld seam. Furthermore, in the failure pattern observed in the spot weld joint it was the parent material of the joint that failed, not the weld. Moreover, the welded joints exhibit higher strength than the adhesively bonded joints, however, the later may be used in a wider range of applications than the welded joints.

Our work has led us to conclude that the welded joints are characterised by higher strength than the adhesive joints. While that cannot be argued, it should be remarked that the adhesive joining methods offer other equally significant benefits, e.g. no adherent failure in the joint or sealing.

\section{REFERENCES}

1. Blicharski M.: Wstęp do inżynierii materiałowej. WNT, Warszawa 2003.

2. DIN EN 1465:2009 -- Adhesives - Determination of tensile lap-shear strength of bonded assemblies.

3. DIN EN ISO 527-1:2012 -- Determination of tensile properties. 
4. Ferenc K., Ferenc J.: Konstrukcje spawane. Połączenia. WNT, Warszawa 2000.

5. Godzimirski J., Kozakiewicz J., Łunarski J., Zielecki W.: Konstrukcyjne połączenia klejowe elementów metalowych w budowie maszyn. Oficyna Wydawnicza Politechniki Rzeszowskiej, Rzeszów 1997.

6. Godzimirski J.: Wytrzymałość doraźna konstrukcyjnych połączeń klejowych. WNT, Warszawa 2002.

7. Klimpel A.: Spawanie zgrzewnie i cięcie metali. Wydawnictwo Naukowo-Techniczne, Warszawa 1999.

8. Kuczmaszewski J.: Technologia śmigłowców. Teoria i technika klejenia. Wydawnictwa Uczelniane PL, Lublin 1990.

9. Penkała P., Płowaś B.,: The influence of currant mma welding on the tensile strength of joint. Advances in Science and Technology Research Journal, 8/2014, 43-48.

10. PN-EN 10139:2016-04
11. Rotella G., Alfano M., Schiefer T., Jansen I., Evaluation of mechanical and laser surface pretreatments on the strength of adhesive bonded steel joints for automotive industry, Journal of Adhesion Science and Technology, 2016, 30,747-758.

12. Rudawska A., Kuczmaszewski J.: Klejenie blach ocynkowanych. Wydawnictwa Uczelniane PL, Lublin 2005.

13. Rudawska A., Łukasiewicz M.: Wpływ obróbki mechanicznej na wytrzymałość połączeń klejowych wybranych materiałów konstrukcyjnych. Przegląd Spawalnictwa nr 8/2008.

14. Sobieszczański J.: Spajanie. Oficyna Wydawnicza Politechniki Warszawskiej, Warszawa 2004.

15. Urbański T.: The influence of welding deformation types of hybrid node on assembly suitability. Advances in Science and Technology Research Journal, 6/2012, 42-47.

16. Wojciechowski W.: Techniki Wytwarzania. Tom III. Wybrane zagadnienia ze spawalnictwa, Kraków 1990. 